\title{
Medication as a risk factor for falls in older women in Brazil
}

\author{
Suely Rozenfeld, ${ }^{1}$ Luiz Antonio Bastos Camacho, ${ }^{1}$ \\ and Renato Peixoto Veras ${ }^{2}$
}

ABSTRACT Objective. To assess the prevalence of falls and their association with the use of medications among elderly women in the city of Rio de Janeiro, Brazil. Falls among the elderly are likely to gain additional public health importance in Brazil and many other developing countries given the rapid growth of the elderly populations in those nations.

Methods. A cross-sectional study was carried out with women who were participating in the educational, cultural, and medical care activities of the Open University of the Third Age (OUTA), a group that works to promote the welfare of elderly people in the city of Rio de Janeiro. The women in the study were all 60 years old or older, were able to walk, had no cognitive impairment, and were living in the community (rather than living in a facility exclusively for older persons). A questionnaire was used that asked about falls within the 12 months prior to the interview, medications used in the previous 15 days, current and past health problems, and demographic characteristics. Women who were interviewed face-to-face also had their blood pressure checked. Two outcome variables were defined: (1) "fallers," who had suffered one or more falls (contrasted with "nonfallers") and (2) "recurrent fallers," who had had two or more falls (contrasted with those who had had one or no falls, called "nonrecurrent fallers").

Results. A total of 634 women were interviewed face-to-face at the OUTA facilities. Among these in-person interviewees, $23.3 \%$ reported one fall in the previous year, and $14.0 \%$ reported two or more falls in that period. Considering both prescribed drugs and over-the-counter drugs, only $9.1 \%$ of these women were not using any medications, $52.7 \%$ were using 1 to 4 medications, $34.4 \%$ were using 5 to 10 , and $3.8 \%$ were using 11 to 17 medications. In comparison to nonusers, users of diuretics who also suffered from musculoskeletal disease were 1.6 times as likely to report having suffered a single fall in the preceding year, after adjusting for cardiovascular disease. Recurrent falls were reported 2.0 times as often among beta-blocker users as among nonusers, after adjusting for cardiovascular disease. The risk of recurrent falls among users of anxiolytics/sedatives who had postural hypotension was 4.9 times as high as among nonusers.

Conclusions. Our data indicate an association between single falls and recurrent falls and several groups of medications. Some falls could be avoided through the more rational use of drugs, and measures should be developed and implemented to encourage this.

Key words Aged, drug therapy/adverse effects, accidental falls, Brazil.

1 Fundação Oswaldo Cruz, Escola Nacional de Saúde Pública, Rua Leopoldo Bulhões, 1480, $8^{\circ}$ Andar, Manguinhos, Rio de Janeiro-RJ, Brazil. Send correspondence to: Suely Rozenfeld, Fundação Oswaldo Cruz, Escola Nacional de Saúde Pública, Rua Leopoldo Bulhões, 1480, $8^{\circ}$ Andar, Manguinhos, Rio de Janeiro-RJ, Brazil 21041-210; telephone: 5521 25982631/55 21 22706772; e-mail: rozenfel@ensp.fiocruz.br

2 Universidade do Estado do Rio de Janeiro, Instituto de Medicina Social, Rio de Janeiro-RJ, Brazil 20559-900.
Falls among older persons have been a concern in many developed countries of the world, and this problem is likely to become a growing public health issue in many developing nations as well. For example, in the United States of America most of the fatal injuries in persons over the age of
65 are related to falls, $42 \%$ of fall injury events require hospitalization, and more than $60 \%$ of fall injury events with a hip fracture result in discharge to a nursing home $(1,2)$.

In Brazil in 1995 the mortality rate from external causes was 24.7 per 100000 among women of all ages (3). 
Among people who were 60 years old or older, external causes were the fifth cause of mortality in the southern and western regions of the country. Of all the deaths from falls, $41 \%$ of them occurred among people 60 or older.

These falls among older persons are of increasing epidemiological concern in Brazil, given the aging of the country's population. In 1940 there were fewer than 2 million persons in Brazil aged 60 or older (4). By 1996, that population had reached 12.4 million, with growth at double the rate for the country as a whole. The number of people over 80 years old also grew substantially, from 166000 in 1949 to 1.5 million in 1996. In Brazil, as in most other developing countries, this demographic trend is taking place in the midst of poverty and a scarcity of resources to deal with the special needs of the elderly.

Falls associated with the use of medications may be a major health issue in developing countries, where drugs are often used without medical supervision, drug regulation is loose or unenforced, and there are few controls on advertising (5). The specific magnitude of the problem needs to be assessed. This study had two primary purposes. One was to determine the prevalence of falls among a group of women 60 or older in the city of Rio de Janeiro, Brazil, who were living in the community (that is, not living in a facility or institution exclusively for older persons). The second purpose was to examine the relationship between those falls and the medications that those women were taking.

\section{SUBJECTS AND METHODS}

\section{Study population}

We conducted a cross-sectional study in a group of women who regularly attended the activities of an organization that works to promote the welfare of people aged 60 years and older through educational, cultural, and medical care activities. The initiative, known as Universidade Aberta da Terceira Idade (Open University of the Third Age, or OUTA), is sponsored by the State University of Rio de Janeiro and operates only in the city of Rio de Janeiro. For this study, eligible subjects were women, 60 years old and over, able to walk without the aid of devices such as canes and walkers, able to communicate, and free of cognitive impairment. Women identified from the records of OUTA were sent a letter that explained the objectives of the study and that invited them to participate.

\section{Data collection}

The women who gave their written informed consent were interviewed between July and December 1996. The interviewers all had a university degree and had also been trained by the investigators in the use of the study questionnaire and in other data collection procedures. A standardized questionnaire was used to collect information from the participants on falls, use of medications, consumption of alcoholic beverages, body weight and height, past and current medical conditions, and sociodemographic characteristics. After the in-person interviews on the OUTA premises, study subjects had their blood pressure checked according to standard methods.

In addition, some other women from the OUTA program were interviewed by telephone. They were asked about their age, family income, and history of diseases and falls, in order to check the differences between them and the subjects interviewed face-to-face at the OUTA facilities. Data from the telephone interviews were not considered in the analysis of falls and medications.

\section{Study variables}

The main response variable was the occurrence of falls within the 12 months prior to the interview. This approach assumed that the subjects' characteristics were relatively stable over this period. A fall was defined as an unintentional change in position, resulting in falling to the ground or to some other lower level, that was not the result of a stroke or some other major intrinsic event or of an overwhelming hazard of the kind that would cause a fall in a young, healthy person. Two outcome variables were defined: (1) fallers, with one or more falls (contrasted with nonfallers), and (2) recurrent fallers, with two or more falls (contrasted with those who had one or no falls, called nonrecurrent fallers). The participants were asked about each fall's place, time, and the conditions thought to have caused it; its immediate consequences (e.g., unconsciousness or injuries with fractures or open wounds); and the need for medical care, including hospitalization.

Subjects were asked to report all medications taken within the 15 days prior to the interview, including drugs that had been prescribed and over-thecounter drugs. We disregarded phytotherapeutic and homeopathic drugs and products whose composition was not identified even after checking in local pharmacies. We took the names of the drugs from their containers, inserts, or prescriptions or from the reports by the interviewees.

We used the anatomical-therapeuticchemical coding system of the World Health Organization Collaborating Centre for Drugs Statistics Methodology (6) to classify the medications, focusing especially on drugs that previous studies had indicated were associated with falls. We categorized the drugs into the following groups: antihypertensives, beta-blockers ( $\beta$ blockers), anxiolytic/sedatives, other psychoactive agents, diuretics, and topical eye medications ( $\beta$-blockers used to reduce intraocular pressure in patients with glaucoma).

The questionnaire contained an inventory of past health problems (ones in the previous 12 months) and current health problems. The inventory emphasized musculoskeletal disorders, cardiovascular diseases, neurological diseases/symptoms, and other problems thought to be more relevant to the elderly or to relate to falls.

We defined postural hypotension as a decline in systolic blood pressure greater than $20 \mathrm{~mm} \mathrm{Hg} 3$ minutes after moving from the supine to the standing position. We calculated the body 
mass index (BMI) for each of the participants from the weight and height data that they had provided.

The data collected on sociodemographic characteristics included age, educational level, number of persons living in the household, marital status, occupational status (employed outside the home or handling domestic duties in the home), and income. We also recorded the type, quantity, and duration of consumption of alcoholic beverages, and estimated ethanol intake in grams.

\section{Data analysis}

The strength of the association between falls and the covariates of interest was measured with the odds ratio and the $95 \%$ confidence interval. The statistical significance of differences among proportions and means was assessed, as appropriate, with the chi-square $\left(\chi^{2}\right)$ test (Pearson's $\chi^{2}$ and Mantel-Haenszel $\chi^{2}$ for trend), KruskalWallis test, Mann-Whitney test, and one-way analysis of variance. Stratified analysis was applied to address confounding and interaction. Variables selected for their relevance and statistical significance $(P<0.10)$ in the bivariate analysis were entered into the logistic regression model in a stepwise fashion.

\section{RESULTS}

From 1043 women in the OUTA records, 1033 met the eligibility crite- ria, and 634 of these 1033 (61.4\%) were interviewed face-to-face at the OUTA facilities. Of the 399 eligible women who were not interviewed at the OUTA facilities, 169 of them were interviewed by telephone. For the women interviewed over the telephone, their age, income, and frequency distribution of fall injuries and preexisting health conditions were similar to those for the 634 women who were interviewed face-toface. On the other hand, the telephone interviewees had a lower frequency of falls $(24.3 \%$ vs. $37.3 \%)$, of musculoskeletal diseases $(60.9 \%$ vs. $78.5 \%)$, and of cardiovascular diseases $(55.6 \%$ vs. $69.2 \%$ ). To analyze the association between drug use and falls we excluded the women who were interviewed by telephone and considered the data from 631 of the 634 in-person interviewees for whom complete information was available.

The mean age of the 634 face-to-face interviewees was 69.3 years, and 389 of them $(61.4 \%)$ were between 60 and 69 years old. Of the 634, 169 of them $(26.7 \%)$ were married, and only 204 of them (32.2\%) lived alone. Educational level was higher than elementary school in 359 of the 634 (56.6\%). Of the 634,540 of them $(85.2 \%)$ were housewives. BMI was assessed for 580 of the women. Their mean BMI was 25.3; 207 of the $580(35.7 \%)$ had a BMI between 25 and 29.9 , and 76 of them (13.1\%) had a BMI above 30. Postural hypotension was found in 118 of 595 women $(19.8 \%)$. Of the 634 women, 402 of them $(63.4 \%)$ reported alcohol intake.
At least one fall in the previous year was reported by 237 of the 634 women (37.4\%); 148 of them (23.3\%) reported one fall, and 89 of them (14.0\%) reported two or more falls. From a total of 326 falls, 255 of the falls $(78.2 \%)$ occurred outside the house. The falls resulted in a total of 368 injuries, including: problems in soft tissues (146 of 368, or $39.7 \%$ ), open wounds (88, or $23.9 \%$ ), sprains $(41$, or $11.1 \%$ ), and bone fractures (30, or $8.2 \%)$. Of the 326 falls, only 87 of them $(26.7 \%)$ received ambulatory care (of those 87 , in 61 of them $(70.1 \%$ ), a drug was prescribed); 7 of the 326 falls $(2.1 \%)$ required hospitalization.

Overall, the 634 interviewees consumed a mean of 4.0 medications. Of the 634 women, 58 of them $(9.1 \%)$ were not using any medication, 334 of them $(52.7 \%)$ used 1 to 4 medications, 218 (34.4\%) used 5 to 10 , and $24(3.8 \%)$ used 11 to 17 medications. Of the 2510 products in total, 2107 of them (83.9\%) had been prescribed by a physician. Of 517 different chemical entities, 289 of them $(55.9 \%)$ contained one substance and $228(44.1 \%)$ had two or more. The 10 medications used most often were acetylsalicylic acid, bromazepam, diclofenac, nifedipine, hydrochlorothiazide + amiloride, ascorbic acid, calcium, chlorthalidone, propranolol, and enalapril.

Table 1 presents information on the distribution of subjects among nonfallers, fallers, nonrecurrent fallers, and recurrent fallers. The table shows, for selected drug groups, the odds ratio $(\mathrm{OR})$ and $95 \%$ confidence interval (CI)

TABLE 1. Association of falls and recurrent falls with selected therapeutic drug groups, as indicated by odds ratio (OR) and $95 \%$ confidence interval (Cl), Rio de Janeiro, Brazil, 1997a

\begin{tabular}{|c|c|c|c|c|c|c|c|c|c|c|c|c|}
\hline Therapeutic group & \multicolumn{2}{|c|}{$\begin{array}{c}\text { Nonfallers } \\
(0 \text { falls }) \\
(n=394) \\
\end{array}$} & \multicolumn{2}{|c|}{$\begin{array}{c}\text { Fallers } \\
(\geq 1 \text { fall }) \\
(n=237)\end{array}$} & OR & $95 \% \mathrm{Cl}$ & \multicolumn{2}{|c|}{$\begin{array}{c}\text { Nonrecurrent } \\
\text { fallers } \\
(\leq 1 \text { falls }) \\
(n=542) \\
\end{array}$} & \multicolumn{2}{|c|}{$\begin{array}{c}\text { Recurrent } \\
\text { fallers } \\
(\geq 2 \text { falls }) \\
(n=89)\end{array}$} & OR & $95 \% \mathrm{Cl}$ \\
\hline Antihypertensives & 111 & 28.2 & 72 & 30.4 & 1.11 & $0.78-1.58$ & 153 & 28.2 & 30 & 33.7 & 1.29 & $0.80-2.08$ \\
\hline$\beta$-blockers & 35 & 8.9 & 31 & 13.1 & 1.54 & $0.92-2.58$ & 50 & 9.2 & 16 & 18.0 & 2.16 & $1.17-4.00$ \\
\hline Anxiolytics/sedatives & 78 & 19.8 & 52 & 21.9 & 1.14 & $0.77-1.69$ & 105 & 19.4 & 25 & 28.1 & 1.63 & $0.98-2.71$ \\
\hline Topical eye medications & 22 & 5.6 & 12 & 5.1 & 0.90 & $0.44-1.86$ & 30 & 5.5 & 5 & 5.6 & 1.02 & $0.40-2.80$ \\
\hline
\end{tabular}

a The sums across some subgroups are higher than the respective $n$ figures in some groups since some individuals used more than one type of medication. 
TABLE 2. Association of single falls and recurrent falls with groups of drugs, by levels of effect modifiers, as indicated by odds ratio (OR) and $95 \%$ confidence intervals (Cl), Rio de Janeiro, Brazil, 1997.

\begin{tabular}{|c|c|c|c|c|}
\hline & Unadjusted OR & $95 \% \mathrm{Cl}$ & Adjusted OR & $95 \% \mathrm{Cl}$ \\
\hline \multicolumn{5}{|l|}{$\begin{array}{l}\text { Single falls } \\
\quad \beta \text {-blockers }\end{array}$} \\
\hline \multicolumn{5}{|c|}{ Body mass index } \\
\hline$\leq 30$ & 0.68 & $0.25-1.79$ & 0.50 & $0.18-01.41$ \\
\hline$>30$ & 2.81 & $1.31-6.10$ & 1.97 & $0.91-4.28$ \\
\hline \multicolumn{5}{|l|}{ Diuretics $^{b}$} \\
\hline \multicolumn{5}{|c|}{ Musculoskeletal disease } \\
\hline No & 0.56 & $0.18-1.65$ & 0.50 & $0.18-01.37$ \\
\hline Yes & 1.69 & $1.07-2.67$ & 1.57 & $1.01-2.46$ \\
\hline \multicolumn{5}{|l|}{ Recurrent falls } \\
\hline$\beta$-blockers ${ }^{b}$ & 2.16 & $1.17-4.00$ & 2.02 & $1.07-3.80$ \\
\hline \multicolumn{5}{|c|}{ Anxiolytics/Sedatives } \\
\hline \multicolumn{5}{|c|}{ Postural hypotension } \\
\hline No & 1.18 & $0.59-2.33$ & 1.18 & $0.62-2.25$ \\
\hline Yes & 4.93 & $1.40-17.64$ & 4.93 & $1.59-15.28$ \\
\hline
\end{tabular}

of falling at least once a year versus not falling, and of falling twice or more a year versus falling once a year or not falling.

As shown in Table 1, out of the six groups of drugs, only one showed a strong and significant association with one or more falls a year; that category was psychoactive agents other than anxiolytics/sedatives. Data for antihypertensives, $\beta$-blockers, anxiolytics/ sedatives, diuretics, and topical eye medications provided no conclusive evidence of association with one or more falls a year.

The analysis of recurrent falls (two or more falls a year) confirmed the strong association with psychoactive drugs other than anxiolytics/sedatives and also disclosed a possible contributing role of $\beta$-blockers (Table 1).

Adjusted odds ratios and $95 \%$ confidence intervals for the association of single and recurrent falls with groups of drugs, by levels of effect modifiers, are shown in Table 2. Each of the six groups of drugs ( $\beta$-blockers, antihypertensives, anxiolytics/sedatives, other psychoactive drugs, diuretics, and topical eye medications) was modeled separately. Income, postural tended to provide insights that could be used in identifying areas for possible interventions.

The frequency of falls (37\%) that we found in a 12-month period among the study subjects in Rio de Janeiro was somewhat higher than the levels reported in community studies in the United States of America (7-10) and in Australia (11), where the frequencies ranged from $23 \%$ to $35 \%$. That was probably because our sample consisted only of women, who tend to fall more frequently than men do.

Our data showed that injuries from falls were usually slightly or moderately severe. In our study the proportion of bone fractures among the injuries from falls $(8.2 \%)$ was similar to the proportion found in other research (7). This level of bone fractures was certainly not inconsequential, and, together with the other types of injuries, it imposed substantial functional limitations on the women in our study.

As in most studies in the elderly, the use of medications among our study subjects was very frequent: $86 \%$ of the women were using medications that had been prescribed, and 35\% were using over-the-counter drugs. Those figures were similar to ones found in a cross-sectional survey of persons 60 years or older living in the city of Rio de Janeiro (12). The mean of 4.0 medications per person in our study is consistent with findings from a study in the United States of America (13). In our sample, $38 \%$ of participants used five or more products. This level of prescribing may be irrational, particularly for active women such as the ones who were involved in the OUTA educational and cultural activities. In comparison to the OUTA participants, other women in this age group may face even worse circumstances, with less access to information and to health services and with possibly a higher proportion of them using a dangerous combination of drugs.

Our findings on the top 10 reported medications and on the average number of drugs per person are consistent with findings previously reported in the scientific literature $(14,15)$. However, according to other research that 
we conducted with this group of women in Rio de Janeiro (16), these women had a distinctive profile regarding the frequency of use of products with fixed drug combination (44\%), the use of drugs inappropriate for the elderly $(17 \%)$, exposure to redundant drugs (14\%), and pharmacological interactions (16\%). Cases of inappropriate medication included the use of tincture of opium to treat diarrhea, psyllium to treat constipation, and Catalin to treat and prevent cataracts.

It is important to stress the difficulties that researchers in Brazil face in analyzing drug utilization. First, there is no complete, updated, official source of information on the composition of commercial products. Therefore, to identify substances, multiple sources have to be searched. Second, there is no database on drug consumption that could be used to validate the data. In spite of those limitations, we believe that our data on medication use are accurate since $66 \%$ of the subjects brought the prescriptions themselves or the medicine containers to the interview.

After removing the effect of potential confounders, three classes of drugs frequently used by older women from OUTA showed moderate effects on the risk of falling: diuretics and falling once a year, and $\beta$-blockers and anxiolytics/sedatives and falling twice or more per year.

The increased likelihood of recurrent falls with the use of $\beta$-blockers is consistent with some previous research (17). However, Tinetti and colleagues (18) did not find any relationship between falling twice or more during the year and antihypertensives or $\beta$-blockers. A meta-analysis (19) showed a significant association between falls and type IA antiarrhythmics and digoxin but not $\beta$ blockers, ACE inhibitors, centrally acting antihypertensives, nitrates, or calcium channel blockers. Different studies may produce dissimilar results due to differences in the characteristics of the subjects, in methods, and in the definition of a fall.

Diuretics appeared associated with single falls, but only in the women with musculoskeletal disorders. The occur- rence of recurrent falls was not influenced by the use of diuretics. The link between the use of diuretics and falls is biologically plausible considering diuretics' side effects, such as cardiac arrhythmias, hypotension, vertigo, weakness, and fluid and electrolyte disorders. However, existing evidence on the role of diuretics in causing one or more falls in a year is conflicting, as some authors have found a positive association (8) whereas others have not $(17,18)$.

In our data set, a substantial proportion of study subjects (21\%) reported using benzodiazepines (the anxiolytics / sedatives group was mostly composed of benzodiazepines). In comparison to nonusers, the users of anxiolytics/ sedatives who had postural hypotension were far more likely to have suffered recurrent falls. In addition, there are some worrisome peculiarities of benzodiazepine use among the women in our study, as described in a previous paper (20). Eighteen percent of study subjects used long-acting benzodiazepines, and $35 \%$ had been using them regularly for over 12 months (20). This rather irrational use may explain the higher odds ratio of recurrent falls that we found in our study as compared to other research findings (21).

According to the scientific literature, the use of benzodiazepines is associated with falls (22) even when controlling for depression and dementia (23). Ryynänen (24) found a five-fold increase in risk of falls related to shortacting benzodiazepine and a two-fold increase for other benzodiazepines titrated in the serum. The use of longacting benzodiazepine in women is an independent risk factor for major injuries (24). Diazepam is an important risk factor for multiple falls (8).

The association that we found between recurrent falls and anxiolytics/ sedatives but not for other psychoactive drugs was much stronger in the presence of postural hypotension. This suggests that postural hypotension may be a marker for the inappropriate simultaneous use of benzodiazepine and a cardiovascular drug.

In summary, this study indicated the magnitude of the problem of falls among elderly women, showed their profile of drug use, and provided evidence of the role of $\beta$-blockers and benzodiazepines in causing recurrent falls.

One of the strengths of this study was that it investigated communitydwelling elderly women, whose exposure to falls and patterns of medication use may be different from those of institutionalized elderly persons. Being more independent and active, community-dwelling elderly persons might have a different pattern of falls as compared to frail institutionalized elderly. It is likely that the communitydwelling elderly are generally healthier and thus less exposed to medications than institutionalized elderly persons of a comparable age. Nevertheless, our data suggest irrational use of medications, with a potential for adverse drug reactions. The frequency of inappropriate medication may be higher in developing countries than in developed countries, since in developing countries control by government agencies is often weaker and advertising tactics are more aggressive (5).

Another strength of our research was that we considered two outcome variables. As Koski (25) and Dunn (26) had found previously, we found differences in risk factors according to the outcome variable chosen, that is, when we compared persons who had fallen once in the preceding year with persons who had fallen twice or more in that period.

The survey data that we have presented here help demonstrate the public health importance of the relationship between medication and falls, which is not subject to regular monitoring. However, with the crosssectional design that we used we did not include elderly persons who had suffered a fall and had either died or moved to a nursing home. Therefore, we have probably underestimated the rate of falls among people 60 and older.

Research on medication and falls raises important methodological issues in terms of assessing exposure. In our study, we used current exposure (medication) as a proxy for past expo- 
sure, a procedure that is usually less reliable. In other research, elderly persons' recall has shown limited accuracy for medications that include steroids, barbiturates, antihypertensives, and thyroid hormones (27); $\beta$ blockers and $\beta$-agonists (13); and antiinflammatories (28). We minimized recall problems by stressing the need to bring the medications themselves or the medication containers or package inserts to the face-to-face interviews.

Another potential limitation of our study was our reliance on recall of falls. However, we believe recall failures were minimized by the fact that our study subjects receive stimulation from the cognitive and psychomotor activities at OUTA.

If we want to try to generalize our results, we must consider the differences between our subjects and subjects in other studies. In terms of the proportion of persons with high blood pressure, we found $47.3 \%$ in our OUTA population vs. $24.9 \%$ in a district in the city of Rio de Janeiro (29). On the other hand, our study included a lower proportion of older elderly individuals
(80 years old or older) in comparison to Brazil as a whole. Just $4.0 \%$ of the women in our study were 80 or older, while $8.3 \%$ of Brazilian men and women who are 60 or older are in that age group of older elderly persons. In addition, the illiteracy rate among our study subjects was nil, in contrast to the $41 \%$ level overall among Brazilian women 60 and older (4). In the various large urban communities in Brazil, middle class persons generally have similar lifestyles, including in terms of knowledge about and access to medical care and pharmaceutical products. Therefore, we believe we can extend our results to the larger urban middle class population of Brazil. One might also argue that the basic biological processes through which a drug interferes with balance so as to cause a fall are probably similar across human populations. The results of this study may be applicable to noninstitutionalized older people in other parts of the developing and developed world to the extent that the burden of diseases in this age group leads to exposure to the same group of drugs. Our results are likely to be more similar to what would be found in other developing countries where inappropriate prescribing and self-medication are common. Whatever the biological contribution of medication to falls in the elderly, it seems legitimate to assume that the inappropriate use of medication can boost the potential for side effects.

In this paper we have shown that falling is a major burden to the health of noninstitutionalized women who were aged 60 or older and living in Rio de Janeiro. Our findings indicate that some falls could be avoided through the more rational use of drugs, and measures should be developed and implemented to encourage this.

Acknowledgments. We gratefully acknowledge the cooperation of the respondents and their families. We also acknowledge the financial support from the Universidade Aberta da Terceira Idade of the State University of Rio de Janeiro and from the Conselho Nacional de Pesquisa e Desenvolvimento (CNPq).

\section{REFERENCES}

1. Tinetti ME, Speechley M. Prevention of falls among the elderly. N Engl J Med. 1989;320: 1055-1059.

2. Sattin RW, Lambert Hubert DA, DeVito CA, Rodriguez JG, Ros A, Bachelli S, et al. The incidence of fall injury events among the elderly in a defined population. Am J Epidemiol 1990;13:1028-1037.

3. Jorge MHPM, Gotlieb SLD. As condições de saúde no Brasil. Rio de Janeiro: Fiocruz; 2000.

4. Camarano AA, Beltrão KI, Pascom ARP, Medeiros M, Goldani A. Como vive o idoso brasileiro? In: Camarano AA, ed. Muito além dos 60 - os novos idosos brasileiros. Rio de Janeiro: Instituto de Pesquisa Econômica Aplicada; 1999. Pp. 19-71.

5. United States of America, Office of Technology Assessment. Drug labeling in developing countries. Washington, D.C.: United States Government Printing Office; 1993.

6. World Health Organization. Anatomical therapeutic chemical (ATC) classification index with defined daily doses (DDDs). Oslo: WHO Collaborating Centre for Drug Statistics Methodology; 2000

7. Tinetti ME, Speechley M, Ginter SF. Risk factors for falls among the elderly persons living in the community. N Engl J Med 1988;319: 1701-1707.

8. Cumming RG, Miller JP, Kelsey JL, Davis P, Arfken CL, Birge J, et al. Medications and multiple falls in elderly people: the St Louis OASIS Study. Age Ageing 1991;20:455-461.

9. Grisso JA, Kelsey JL, Strom BL, Chiu GY, Maislin G, O'Brien LA, et al. Risk factors for falls as a cause of hip fracture in women. $\mathrm{N}$ Engl J Med 1991;324:1326-1331.

10. Sheahan SL, Coons SJ, Robbins CA, Martin SS, Hendricks J, Latimer M, et al. Psychoactive medication, alcohol use, and falls among older adults. J Behav Med 1995;18:127-140.

11. Lord SR, Sambrook PN, Gilbert C, Kelly PJ, Nguyen T, Webster IW, et al. Postural stability, falls and fractures in the elderly: results from the Dubbo Osteoporosis Epidemiology Study. Med J Aust 1994;160:684-691.

12. Veras RP. País jovem com cabelos brancos. Rio de Janeiro: Relume Dumará; Universidade do Estado do Rio de Janeiro; 1994.

13. Psaty BM, Lee M, Savage PJ, Rutan GH, German PS, Lyles M. Assessing the use of medications in the elderly: methods and initial experience in the Cardiovascular Health Study. J Clin Epidemiol 1992;45:683-692.
14. Hemminki E, Heikkilä J. Elderly people's compliance with prescriptions, and quality of medication. Scand J Soc Med 1975;3:87-92.

15. Stewart RB, Moore MT, May FE, Marks RG, Hale WE. A longitudinal evaluation of drug use in an ambulatory elderly population. J Clin Epidemiol 1991;44:1353-1359.

16. Mosegui GBG, Rozenfeld S, Veras RP, Vianna CMM. Avaliação da qualidade do uso de medicamentos em idosos. Rev Saude Publica 1999;33:437-444.

17. Hanlon JT, Linzer M, MacMillan JP, Lewis IK, Felder AA. Syncope and presyncope as associated with probable adverse drug reactions. Arch Intern Med 1990;150:2309-2312.

18. Tinetti ME, Inouye SK, Gill TM, Doucette JT. Shared risk factors for falls, incontinence, and functional dependence. JAMA 1995;273:13481353.

19. Leipzig RM, Cumming RG, Tinetti ME. Drugs and falls in older people: a systematic review and meta-analysis: II. Cardiac and analgesic drugs. J Am Geriatr Soc 1999;47:40-50.

20. Huf G, Lopes CS, Rozenfeld S. O uso prolongado de benzodiazepínicos em mulheres de um centro de convivência para idosos. Cad Saude Publica 2000;16:351-362. 
21. Leipzig RM, Cumming RG, Tinetti ME. Drugs and falls in older people: a systematic review and meta-analysis: I. Psychotropic drugs. J Am Geriatr Soc 1999;47:30-39.

22. Ensrud KE, Blackwell TL, Mangione CM, Bowman PJ, Whooley MA, Bauer DC, et al. Central nervous system-active medications and risk for falls in older women. J Am Geriatr Soc 2002;50:1744-1745.

23. Ebly EM, Hogan DB, Fung TS. Potential adverse outcomes of psychotropic and narcotic drug use in Canadian seniors. J Clin Epidemiol 1997;50:857-863.

24. Ryynänen O-P, Kivelä S-L, Honkanen R, Saano V, Laippala P. Benzodiazepines and falling injuries in the elderly. Acta Univ Oul 1993;D265:VII1-VII2.

25. Koski K, Luukinen H, Laippala P, Kivela SL. Physiological factors and medications as predictors of injurious falls by elderly people: a prospective population-based study. Age Ageing 1996;25:29-38.

26. Dunn JE, Rudberg MA, Furner SE, Cassel CK. Mortality, disability, and falls in older persons: the role of underlying disease and disability. Am J Public Health 1992;82:395-400.

27. Paganini-Hill A, Ross RK. Reliability of recall of drug usage and other health-related information. Am J Epidemiol 1982;116:114-122.
28. West SL, Savitz DA, Koch G, Strom BL, Guess HA, Hartzema A. Recall accuracy for prescription medications: self-report compared with database information. Am J Epidemiol 1995;142:1103-1112.

29. Klein $\mathrm{CH}$, Souza-Silva NA, Nogueira AR, Bloch KV, Campos LHS. Hipertensão arterial na Ilha do Governador, Brasil. II. Prevalência. Cad Saude Publica 1995;11:389-394.

Manuscript received 27 September 2002. Revised version accepted for publication on 31 March 2003.

RESUMEN Objetivo. Determinar la prevalencia de caídas en mujeres mayores de Río de Janeiro, Brasil, y su asociación con el consumo de medicamentos. Desde el punto de vista de la salud pública, las caídas de adultos mayores están cobrando mayor importancia en Brasil y muchos otros países en desarrollo debido al rápido crecimiento de su población de mayor edad.

\section{factor de riesgo de caídas en mujeres mayores de Brasil \\ Los medicamentos como}

Métodos. Se realizó un estudio transversal con mujeres de 60 años o más que participaban en actividades educativas, culturales y sanitarias de la Universidad Abierta de la Tercera Edad (UATE), un grupo dedicado a promover el bienestar de adultos mayores en Río de Janeiro. Las mujeres del estudio podían caminar, no tenían problemas cognitivos y vivían en sus comunidades (es decir, no vivían en colectividades especiales para adultos mayores). Se recopiló mediante un cuestionario aplicado en entrevistas personales la información sobre las caídas que estas mujeres habían sufrido en los 12 meses anteriores a la entrevista, los medicamentos que tomaban en los 15 días previos, los trastornos de salud pasados y en el momento de la entrevista, así como sus características demográficas. A las mujeres entrevistadas personalmente se les tomó también la presión arterial. Se definieron dos variables de interés: 1) personas que sufrieron una o más caídas; 2) personas que sufrieron más de una caída (por comparación con las que sufrieron una caída o ninguna).

Resultados. Del total de 634 mujeres entrevistadas personalmente en las instalaciones de la UATE, 23,3\% informaron haber sufrido una caída en el año previo y $14,0 \%$ manifestaron haber sufrido dos o más caídas en ese período. De las 634, solo 9,1\% no habían tomado ningún medicamento, ni de venta libre ni recetado, mientras que $52,7 \%$ tomaban de 1 a 4 medicamentos; 34,4\% tomaban de 5 a $10 ; y$ y $8 \%$ tomaban entre 11 y 17. En comparación con las que no tomaban diuréticos, las mujeres que los tomaban y también sufrían de enfermedades osteomusculares tuvieron 1,6 más probabilidades de haber sufrido una caída en el año anterior, aun después de ajustar los datos en función de la presencia de enfermedades cardiovasculares. Las mujeres que tomaban bloqueadores beta informaron 2,0 veces más caídas recurrentes que las que no los consumían, aun habiendo ajustado los datos según la presencia de enfermedades cardiovasculares. El riesgo de caídas recurrentes entre mujeres que sufrían de hipotensión postural y tomaban ansiolíticos o sedantes fue 4,9 veces mayor que entre las que no los tomaban.

Conclusiones. Estos resultados indican que existe una asociación entre las caídas, ya sean una sola o más, y algunos grupos de medicamentos. Algunas caídas podrían evitarse mediante un uso más racional de los medicamentos, por lo que se deben desarrollar e implementar medidas para fomentarlo. 
O arquivo disponível sofreu correções conforme ERRATA publicada no Volume 20 Número 1 da revista. 